\title{
Curriculum Construction and Enterprise Selection for Engineering Leading Talent Training in Computer Specialty
}

\author{
Songlin $\mathrm{Gu}^{\mathrm{a}}$, Ce Zhang ${ }^{\mathrm{b} *}$, Jianan Jiang ${ }^{\mathrm{c}}$, Dianhui $\mathrm{Chu}^{\mathrm{d}}$, Jianxiong $\mathrm{Li}^{\mathrm{e}}$, Weigong $\mathrm{Lv}^{\mathrm{f}}$ \\ School of Computer Science and Technology \\ Harbin Institute of Technology at Weihai \\ Weihai, Shandong Province, 264209, China \\ a gusonglin828@163.com, bhangce@hitwh.edu.cn, csusan_jin@163.com, dcdh@hitwh.edu.cn, e13561816673@163.com, \\ flwgswl@sina.com
}

\begin{abstract}
The shortage of engineering leading talents with outstanding engineering innovation and practice ability facing computer top-notch industry has become an obstacle to the development of high-end industry. Aiming at the curriculum learning and enterprise practice need of engineering leading talent, we put forward the curriculum construction and enterprise selection plan for computer specialty engineering leading talent training. Starting from the cultivation goal of computer specialty innovation and engineering leadership, this paper gives the plan of professional courses and engineering leading talent and management courses, and gives a variety of types of high-end industrial enterprises selection strategy combined with the computer professional classification. Finally, it is pointed out that school-enterprise cooperation education system has to be built, and the cooperative education managing mechanism combining individual development and flexibility management also has to be established, which is an important key to promote the rapid growth of the top-notch innovative engine ering leading talents.
\end{abstract}

Keywords-computer specialty; engineering leading talents; curriculum construction; school-enterprise cooperation education

\section{INTRODUCTION}

In recent years, after talent development by amount of information college, computer college and software college of Chinese universities and various types of private computer technology training institutions, the number of computer specialists has gradually met the needs of social development. However, there is still a lack of engineering leading talents who have top-notch innovation and engineering leadership, which is required in high-end industries, and has become a short-cut of industry development. The implementation of engineering leading talent training program is an important way to solve the shortage of top-level engineering leading talents. Some wellknown uni versities in the United States have carried out talent cultivation programs focusing on engineering leadership training[1-4]. In recent years, many colleges and uni versities in China have also carried out relevant practices [5-7].

Engineering Leading Talents Program(ELTP)[8-11] is one of the most important measures to implement top-notch

The research was sponsored by the 2016 Research and Practice on Engineering Leading Talent Training Mode for Engineering Top-notch Talents of Shandong Province Undergraduate Teaching Reform Research Project (B2016M016) innovative talents, aiming to choose budding students, build nice platform, find good enterprises, make opportunities through multiple channels and cultivate leading talents with practical ability, innovation and engineering leadership.

ELTP needs to be jointly implemented by school and enterprises. When participating students study professional courses in school, they should also learn the management courses related to engineering leadership. After the necessary scientific research and practice in the school, students then enter the enterprise to complete the real engineering practice, promote leadership and business management practices, and ultimately achieve the goal. The first classroom in school and the second classroom in enterprise practice form a general ELTP classroom, which expand the traditional classroom function of cultivating students to become engineering leading talents.

Based on the computer specialty characteristic and the goal of cultivating engineering leading talents, this paper puts forward the curriculum construction and the enterprise selection plan for the training the engineering leading talents in computer specialty. The paper builds the curriculum plan, consisting of the basic courses of computer specialty, the engineering leading talent management courses and enterprise cooperative courses, and gives a selection strategy for various types of high-end industries.

\section{COURSE RESOURCE CONSTRUCTION}

The whole curriculum system is rooted in the traditional courses of computer science of school education, and strengthen engineering practice and leadership knowledge through special courses, including management and leadership course, school-enterprise cooperation courses and engineering targeted courses of college research center. Each course has its own focus. Management and leadership courses focus on the knowledge of management and engineering leadership, which are the rare non-professional theory and technology courses in engineering education, and can teach students management knowledge essentials with engineering leadership as the core. School-enterprise cooperation courses teach clear development technology, engineering management and enterprise culture, which have specific enterprise style and are taught by 
enterprise senior staff (technical staff, business staff, and management staff). Targeted courses of college research center are opened for the students to do researches and develop engineering project in research center, which more emphasis on the engineering development technology learning directed by solutions to specific questions. Due to the pertinence, this kind of course can achieve the immediate effect that the traditional course cannot receive. It helps to enhance students' level of engineering research and development and confidence.

\section{COURSE BUILD IN SCHOOL}

The courses system of engineering leading talents training program is an important way to complete the accumulation of basic knowledge of leadership. The framework is shown in Fig. 1 .

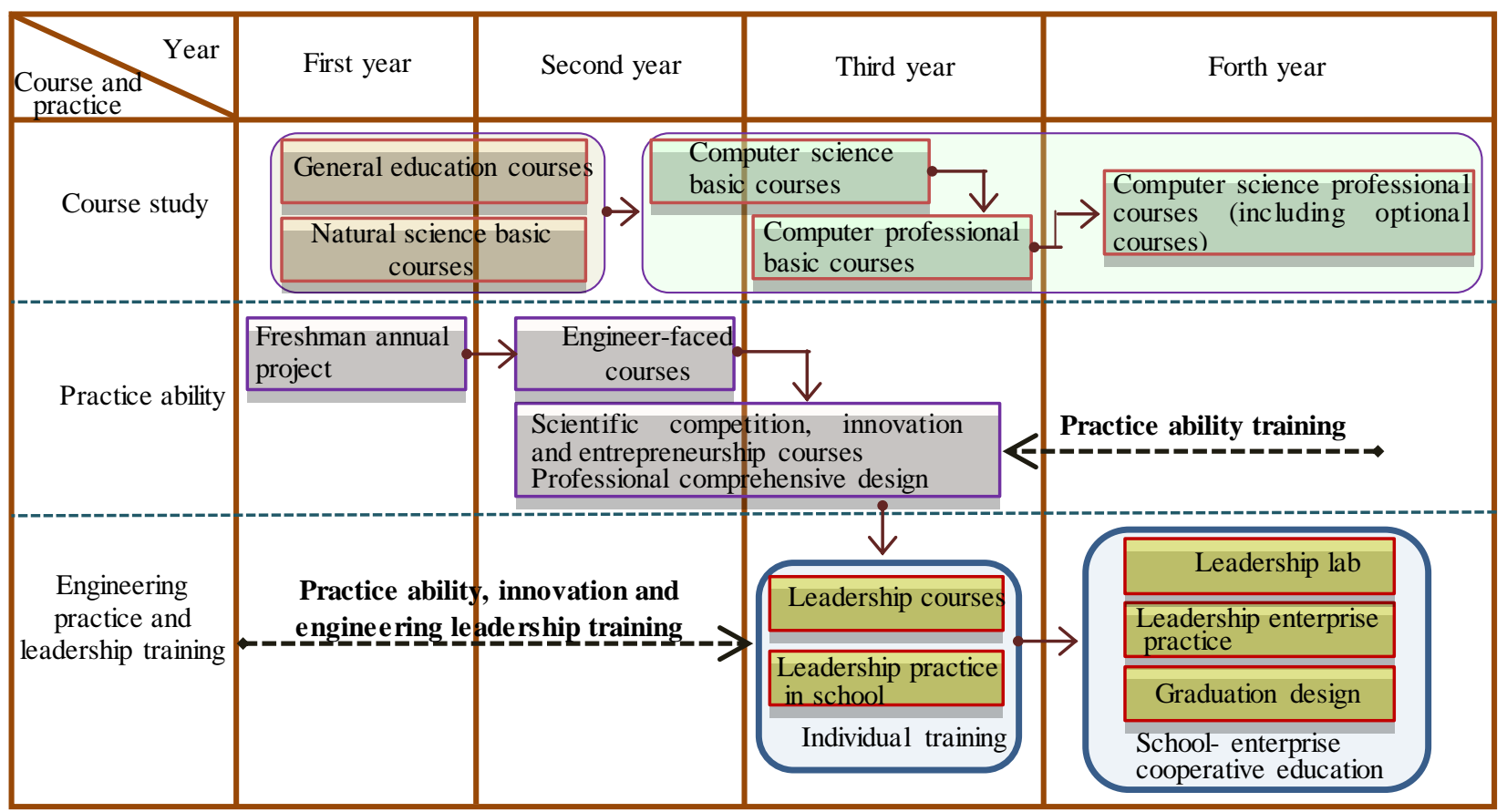

Fig. 1. Course system framework of engineering leading talent students

The engineering leading talent training program is implemented on this basis, including leadership course and enterprise leadership practice, mainly including two parts:

First, in computer college, we set up teams to carry out innovation and entrepreneurship training program. The program is composed of teachers and students who are responsible for the project development in college, and strengthen engineering leadership training. Second, in the graduation design stage, students intern in the enterprises and integrate into enterprise senior management team or engineering planning design group, and to be trained from engineering technology, planning, management and many aspects. In postgraduate stage, we hope that students can reenter the enterprise to be trainee, and more deeply research and practice in engineering application.

College intends to set up courses of enterprises and services intelligent computing systems and large-scale information security. At the same time, the college will cooperate with enterprises to set up courses for integrated innovation training and engineering leadership training in the field of computer science. These courses will be offered to juniors, seniors and admitted students for elective.

Course construction content of engineering leading talent concretely includes the following:
(1)Freshman year

\begin{tabular}{|c|c|}
\hline $\begin{array}{l}\text { Course learning and engineering } \\
\text { practice }\end{array}$ & $\begin{array}{l}\text { The goal of a leading talent training } \\
\text { program }\end{array}$ \\
\hline $\begin{array}{l}\text { General education, such as } \\
\text { advanced } \\
\text { languages }\end{array}$ & Establish leadership core values \\
\hline $\begin{array}{l}\text { Natural science foundation and } \\
\text { professional foundation, such as } \\
\text { advanced language, physics and so } \\
\text { on }\end{array}$ & Form basic knowledge \\
\hline Freshman annual program & $\begin{array}{l}\text { Contact with the basic concept of } \\
\text { program }\end{array}$ \\
\hline \multicolumn{2}{|l|}{ (2) Sophomore } \\
\hline $\begin{array}{l}\text { Course learning and engineering } \\
\text { practice }\end{array}$ & $\begin{array}{l}\text { The goal of a leading talent training } \\
\text { program }\end{array}$ \\
\hline General education & Strengthen the core values of leadership \\
\hline $\begin{array}{l}\text { Natural science basic and } \\
\text { professionalbasic course }\end{array}$ & $\begin{array}{l}\text { Form a solid foundation of natural } \\
\text { science and professional knowledge }\end{array}$ \\
\hline Project-based curriculum design & $\begin{array}{l}\text { Contact and be able to carry out } \\
\text { preliminary project design }\end{array}$ \\
\hline Specialty competition & $\begin{array}{l}\text { Master the professional foundation } \\
\text { from the depth }\end{array}$ \\
\hline Professional integrated design & Gain breadth and depth of expertise \\
\hline $\begin{array}{l}\text { Innovation and entrepreneurship } \\
\text { plan }\end{array}$ & $\begin{array}{lrr}\begin{array}{l}\text { Contact } \\
\text { innovation } \\
\text { practice }\end{array} & \begin{array}{r}\text { basic } \\
\text { and }\end{array} & \begin{array}{r}\text { undergraduates } \\
\text { entrepreneurship }\end{array} \\
& & \\
\end{array}$ \\
\hline
\end{tabular}


(3) Junior

\begin{tabular}{|c|c|}
\hline $\begin{array}{l}\text { Course learning and engineering } \\
\text { practice }\end{array}$ & $\begin{array}{l}\text { The goal of a leading talent training } \\
\text { program }\end{array}$ \\
\hline Professional and field courses & $\begin{array}{l}\text { Master the core expertise in computer } \\
\text { science and technology }\end{array}$ \\
\hline Basic professional courses & $\begin{array}{l}\text { Develop students' abilities of } \\
\text { abstraction, design reasonable overall } \\
\text { goal and solutions }\end{array}$ \\
\hline Specialty competition & $\begin{array}{l}\text { Reasonably dominate the time, learn in- } \\
\text { depth training }\end{array}$ \\
\hline Professional integrated design & $\begin{array}{l}\text { Overall project design capability } \\
\text { training, give the overall solution. }\end{array}$ \\
\hline $\begin{array}{l}\text { Innovation and entrepreneurship } \\
\text { plan }\end{array}$ & $\begin{array}{l}\text { Management of time and resources, } \\
\text { arrange personal time scientifically, and } \\
\text { use effective methods to manage } \\
\text { personalresources }\end{array}$ \\
\hline School practice of leading talent & $\begin{array}{l}\text { Professional ethics, cultivating the } \\
\text { integrity of the leading talent, and a } \\
\text { sense of responsibility }\end{array}$ \\
\hline Leading talent courses & $\begin{array}{l}\text { Form efficient group, decompose and } \\
\text { need analyze according to the nature of } \\
\text { the mission, construct effective group to } \\
\text { achieve the task based on the needs }\end{array}$ \\
\hline \multicolumn{2}{|l|}{ (4) Senior } \\
\hline $\begin{array}{l}\text { Course learning and engineering } \\
\text { practice }\end{array}$ & $\begin{array}{l}\text { The goal of a leading talent training } \\
\text { program }\end{array}$ \\
\hline Professionaland field courses & $\begin{array}{l}\text { Establish a broader pool of professional } \\
\text { and domain knowledge of the leading } \\
\text { talent }\end{array}$ \\
\hline Orientation courses & $\begin{array}{l}\text { Field orientation knowledge needed by } \\
\text { practice base }\end{array}$ \\
\hline
\end{tabular}

Senior, Cont.

\begin{tabular}{l|l}
\hline Graduation design & $\begin{array}{l}\text { Combining with the cultivation of } \\
\text { leading talents, not only has the leading } \\
\text { management ability but also the design } \\
\text { ability }\end{array}$ \\
\hline Excellence Program (Enterprise) & Excellent engineering ability training \\
\hline Leading talent lab & $\begin{array}{l}\text { How to make the team have a } \\
\text { responsible sense of conduct }\end{array}$ \\
\hline Leader talent business practice & $\begin{array}{l}\text { How to make the team to achieve the } \\
\text { arduous taskaccording to the demand }\end{array}$ \\
\hline
\end{tabular}

The students who apply for leading talent program will enter the college leading practice base, and consult with teachers in the base about the course option according to the orientation. In principle, the credits can't exceed the requirement.

Then, it is explained by the overview of the main courses of basic courses, professional basic courses, professional core courses, field courses, elective courses and leading talents training of the computer institute where the responsible person is located (not including basic science course, advanced mathematics, physics, etc.).

\section{A. Engineering Leading Talent Basic Courses}

Engineering leading talent training program starts from school basic courses. In the new round of the training program, we have basically completed the basic curriculum setup for the computer engineering leading talent training program as shown in TABLE I (implemented from 2017). We meticulously plan the course credits and hours, taking the actual situation of students into account.

TABLE I. COMPUTER ENGINEERING LEADING TALENT BASIC COURSES

\begin{tabular}{|c|c|c|c|c|c|c|c|}
\hline Course type & Name & Credit & Class hours & Course type & Name & Credit & Class hours \\
\hline \multirow{2}{*}{$\begin{array}{l}\text { Technical basic } \\
\text { course }\end{array}$} & Circuit $\mathrm{C}$ & 3 & 48 & \multirow{5}{*}{$\begin{array}{l}\text { Professional core } \\
\text { curriculum }\end{array}$} & Data structure & 3.5 & 56 \\
\hline & Circuit experiment & 1 & 16 & & $\begin{array}{c}\text { Design and Analysis of } \\
\text { Algorithms }\end{array}$ & 2.5 & 40 \\
\hline \multirow{7}{*}{$\begin{array}{c}\text { Professional } \\
\text { foundation class }\end{array}$} & $\begin{array}{l}\text { Advanced Language } \\
\text { Programming I }\end{array}$ & 3 & 48 & & $\begin{array}{c}\text { Computer composition } \\
\text { principle }\end{array}$ & 3.5 & 56 \\
\hline & $\begin{array}{l}\text { Advanced Language } \\
\text { Programming II }\end{array}$ & 2 & 32 & & Operating system & 3.0 & 48 \\
\hline & $\begin{array}{l}\text { Introduction to } \\
\text { Computer }\end{array}$ & 2 & 32 & & Computer network & 3.5 & 56 \\
\hline & $\begin{array}{c}\text { Assembly and } \\
\text { Interface Technology }\end{array}$ & 4.5 & 72 & \multirow{2}{*}{$\begin{array}{l}\text { Professional and } \\
\text { field courses - } \\
\text { Computer Theory }\end{array}$} & $\begin{array}{c}\text { Formal languages and } \\
\text { automata }\end{array}$ & 2 & 32 \\
\hline & Digital logic design & 3.5 & 56 & & Compilation principle & 2.5 & 40 \\
\hline & $\begin{array}{c}\text { Set Theory and Graph } \\
\text { Theory }\end{array}$ & 2 & 32 & \multirow{3}{*}{$\begin{array}{l}\text { Profes sional and } \\
\text { field courses - } \\
\text { Computer } \\
\text { Architecture }\end{array}$} & $\begin{array}{c}\text { Embedded system } \\
\text { principle }\end{array}$ & 2.5 & 40 \\
\hline & Mathematical logic & 2 & 32 & & $\begin{array}{l}\text { Intelligent audio and } \\
\text { video monitoring }\end{array}$ & 2.0 & 32 \\
\hline \multirow{3}{*}{$\begin{array}{c}\text { Orientation } \\
\text { Elective Courses } \\
\text { - Algorithms and } \\
\text { Theory } \\
\end{array}$} & $\begin{array}{l}\text { Introduction to } \\
\text { machine learning }\end{array}$ & 2 & 32 & & Distributed Systems & 2 & 32 \\
\hline & Geometric modeling & 2 & 32 & \multirow{3}{*}{$\begin{array}{c}\text { Professional and } \\
\text { field courses - } \\
\text { Software } \\
\text { Engineering }\end{array}$} & Software Architecture & 2.5 & 40 \\
\hline & Scientific visualization & 2 & 32 & & Software Engineering & 2.5 & 40 \\
\hline \multirow{5}{*}{$\begin{array}{l}\text { Orientation } \\
\text { Electives - } \\
\text { Computer } \\
\text { Hardware }\end{array}$} & Mobile computing & 2 & 30 & & Database systems & 3.5 & 56 \\
\hline & $\begin{array}{l}\text { wireless sensor } \\
\text { network }\end{array}$ & 2 & 30 & \multirow{3}{*}{$\begin{array}{c}\text { Professional and } \\
\text { field courses - } \\
\text { Artificial } \\
\text { Intelligence }\end{array}$} & $\begin{array}{c}\text { Introduction to artificial } \\
\text { intelligence }\end{array}$ & 2 & 32 \\
\hline & RFID technology & 2 & 30 & & Pattern recognition & 2 & 32 \\
\hline & $\begin{array}{l}\text { LINUX system } \\
\text { programming }\end{array}$ & 2 & 30 & & $\begin{array}{c}\text { Introduction to machine } \\
\text { learning }\end{array}$ & 2 & 32 \\
\hline & $\begin{array}{l}\text { QT programming } \\
\text { technology }\end{array}$ & 2 & 30 & $\begin{array}{l}\text { Professional and } \\
\text { field courses - } \\
\text { Information } \\
\text { Security }\end{array}$ & Software security & 1.5 & 24 \\
\hline
\end{tabular}


TABLE I, CONT.

\begin{tabular}{|c|c|c|c|c|c|c|c|}
\hline $\begin{array}{l}\text { Orientation } \\
\text { Electives - } \\
\text { Computer } \\
\text { Hardware }\end{array}$ & $\begin{array}{l}\text { ARM Architecture } \\
\text { and Interface } \\
\text { Programming }\end{array}$ & 2 & 30 & \multirow{2}{*}{$\begin{array}{l}\text { Professional } \\
\text { and field } \\
\text { courses - } \\
\text { Information } \\
\text { Security }\end{array}$} & $\begin{array}{l}\text { Computer system } \\
\text { security }\end{array}$ & 2 & 32 \\
\hline \multirow{9}{*}{$\begin{array}{c}\text { Orientation } \\
\text { Electives - } \\
\text { Software and } \\
\text { Services System }\end{array}$} & E-commerce & 2 & 30 & & $\begin{array}{c}\text { Introduction to } \\
\text { Information Security }\end{array}$ & 1.5 & 24 \\
\hline & $\begin{array}{c}\text { Supply Chain } \\
\text { Management System } \\
\text { and Application }\end{array}$ & 2 & 30 & \multirow{5}{*}{$\begin{array}{l}\text { Orientation } \\
\text { Electives - } \\
\text { Graphics and } \\
\text { Multimedia } \\
\text { Computing }\end{array}$} & Computer Graphics & 2 & 32 \\
\hline & $\begin{array}{c}\text { Marketing } \\
\text { management }\end{array}$ & 2 & 30 & & Image Processing & 2 & 32 \\
\hline & $\begin{array}{l}\text { IT enterprise } \\
\text { management }\end{array}$ & 2 & 30 & & Computer vision & 2 & 32 \\
\hline & $\begin{array}{l}\text { Cloud computing } \\
\text { technology }\end{array}$ & 2 & 32 & & Voice signal processing & 2 & 32 \\
\hline & $\begin{array}{l}\text { ERP and product } \\
\text { supply }\end{array}$ & 2 & 32 & & $\begin{array}{c}\text { Cognitive Science and } \\
\text { Brain-computer } \\
\text { Interface } \\
\end{array}$ & 2 & 32 \\
\hline & $\begin{array}{l}\text { E-commerce } \\
\text { technology }\end{array}$ & 2 & 32 & \multirow{3}{*}{$\begin{array}{l}\text { Orientation } \\
\text { Electives - } \\
\text { Natural } \\
\text { Language } \\
\text { Processing }\end{array}$} & Information retrieval & 2 & 32 \\
\hline & $\begin{array}{c}\text { System Analysis and } \\
\text { Design }\end{array}$ & 1 & 20 & & $\begin{array}{c}\text { Natural language } \\
\text { processing technology }\end{array}$ & 2 & 32 \\
\hline & $\begin{array}{c}\text { Software Quality } \\
\text { Assurance and Testing }\end{array}$ & 2.5 & 40 & & $\begin{array}{l}\text { WEB information } \\
\text { processing and } \\
\text { application }\end{array}$ & 2 & 32 \\
\hline \multirow{5}{*}{$\begin{array}{l}\text { Orientation } \\
\text { Elective Courses } \\
\text { - Network and } \\
\text { Information } \\
\text { Security }\end{array}$} & $\begin{array}{l}\text { Network and Social } \\
\text { Introduction }\end{array}$ & 2 & 32 & \multirow{5}{*}{$\begin{array}{c}\text { Orientation } \\
\text { Electives - } \\
\text { Intelligent } \\
\text { Information } \\
\text { Processing }\end{array}$} & $\begin{array}{l}\text { Intelligent audio and } \\
\text { video monitoring }\end{array}$ & 2 & 32 \\
\hline & Basis of cryptography & 2 & 32 & & $\begin{array}{l}\text { Operations Research } \\
\text { and Optimization } \\
\text { Methods }\end{array}$ & 2 & 32 \\
\hline & $\begin{array}{l}\text { Information content } \\
\text { security }\end{array}$ & 2 & 32 & & Smart robot & 2 & 32 \\
\hline & Information theory & 2 & 32 & & Intelligent decision & 2 & 32 \\
\hline & Cyber security & 2 & 32 & & support system & 2 & 32 \\
\hline
\end{tabular}

In the TABLE I, we add seven types of directional elective courses, five major types of specialty and field courses, so that admitted students can choose the courses that adapt to their own technology direction or tend to theory, which will offer necessary store for following engineering practice and management.

\section{B. Engineering leading talent management courses and enterprise cooperative courses}

The duration of such courses can be attributed to graduation internship and graduation design class hours, including:

(1) Guide of classic management theory and cases, leadership and communication, project management, organizational behavior and team building courses;

Enterprise and service intelligent computing system, largescale information security project courses;

Comprehensive training courses facing subject specific fields or industries, which are co-operated by computer college and enterprise;

Courses oriented computer engineering leading training.

In the spring semester or summer primary semester, a series of "Engineering Leadership" courses will be offered to students enrolling in engineering leading training programs, including Leadership Theory and Practice (24 hours), Leadership and Communication (24 hours), Project Management (24 hours), Organizational Behavior and Team Building (24 hours), which will enable shortlisted students to complete the store of enterprise leadership and organization coordinating knowledge and ability through the leadership courses.

After the courses are finished, a team will be set up to carry out innovation and entrepreneurship training in accordance with their respective major and discipline so as to strengthen engineering leadership training. In this regard, our college has a number of computer-oriented institutes / research laboratories that provide various types of real projects for students to practice. We sort out as follows: engineering practice leading talent facing enterprise and service intelligent computing, engineering practice leading talent facing information security, engineering practice leading talent facing Internet of things and embedded system, engineering practice leading talent facing bioinformatics, engineering practice leading talent facing network analysis technology, engineering practice leading talent facing visual computing and machine intelligence, engineering practice leading talent facing parallel computing, engineering practice leading talent facing big data management technology, engineering practice leading talent facing intelligent multimedia technology.

These research directions and corresponding engineering projects or research topics basically cover the major areas of computer science and the mainstream of the computer industry, which can support the preliminary engineering project practical ability that students should have while entering the enterprise for internship. After students enter the college scientific 
research labs, we will invite lab teachers to conduct in research projects to encourage students to improve their scientific research ability, so that they have the ability to quickly adapt themselves to enter the enterprise.

After finishing the series of school leadership courses, as well as college research practice exercises, the students will be recommended by the college to the relevant enterprises. Then both the mentors of college and enterprise will instructor then to intern and practice together.

\section{ENTERPRISE SELECTION}

Over the years, our interaction with the enterprises has laid an important foundation for the engineering leading talent training program, mainly reflecting in: excellent domestic IT practice bases have been established to provide senior students a platform for industrialization practice and cultivate engineering leading talents with technological innovation and management ability; cooperating laboratory has been created to provide junior students a platform for project development, learning and practice, and cultivate engineering leading talents with basic project development ability and leadership; experience of combination of school education and enterprise education has been accumulated, and a large number of highquality engineering talents will be developed for country and society.

In recent years, it has been a nice mechanism that college senior students enter the IT enterprises to do industry internship. Until August in 2016, nearly 700 students have been sent to intern for no longer than 10 months. A number of industrial intern bases are constructed in the well-known IT enterprises in the main dispatching places, including Beijing, Shanghai, Shenzhen, Dalian and some other places.

There are nearly 70 internship bases, including 8 in Shanghai, 4 in Wuxi, 3 in Hangzhou, 2 in Suzhou, 12 in Beijing, 4 in Jinan, 8 in Qingdao, 3 in Weihai, 9 in Dalian, 5 in Guangdong and 7 in other cities. The distribution can be seen in Fig. 2.

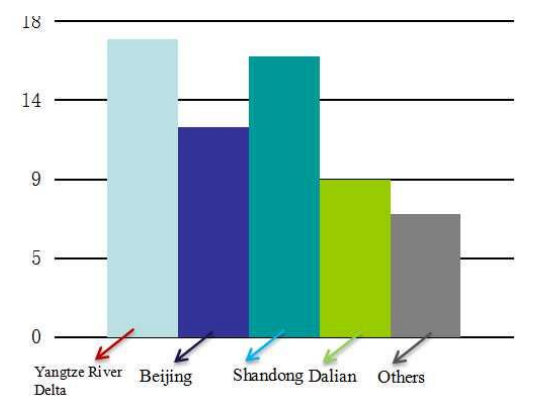

Fig. 2. The number of internship base area distribution

According to the basic categories in the large computer industry, a large number of internship bases can be divided into six types as described in Fig. 3 below: Large international software companies, software outsourcing companies, digital game companies, Internet of things and embedded companies, Internet companies, e-commerce companies.

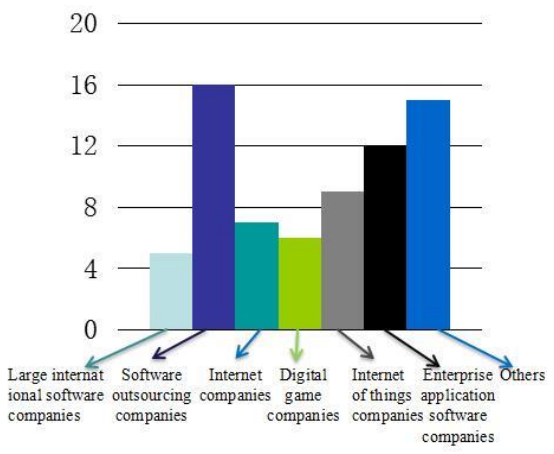

Fig. 3. Quantity distribution of practice base type

On the one hand, senior students enter internship bases, receive industrial education, participate in enterprise $\mathrm{R} \& \mathrm{D}$ projects, and assist the enterprise managing staff. On the other hand, junior students enter the school-enterprise cooperating lab, study and practice in enterprise project development and make necessary preparation for smoothly entering enterprise internship base.

\section{CONCLUSION}

The engineering leading talent training program oriented to computer science needs to give full play to the advantages of course teaching by different types of teachers in college and engineering development and enterprise management led by supervisor mentor. Cross cooperation education system participated by various types of staff and cooperating education management mechanism integrating individual training and flexibility management are built to promote the rapid growth of top-notch innovative engineering leading talents. In the process of high engineering education oriented to industry, the steady implementation of the training plan will surely help cultivate innovative engineering leading talents with strong competitiveness, which is of great value to the training of topnotch innovative engineering leading talents, provide reference for more subjects and more universities to train engineering leading talents, and provide high-end personnel support for the future new-type industrialization and sustainable economic and social development in China.

\section{REFERENCES}

[1] Schuhmann R J. Engineering leadership education: the search for definition and a curricular approach[J] . Journal of Stem Education,2010(11): 61-69.

[2] Kalkhoff M, Athreya K S, Rover D, et al. Work in progress-highlights and challenges of a student driven co-curricular leadership program//Frontiers in Education Conference, 2009. FIE09, 39th IEEE. IEEE, 2009: 1 2.

[3] Cui W X, Zhang D. Student Leadership Project at the University of Maryland[J]. World Education Information, 2013(11): 18-23.

[4] Athreya K S, Kalkhoff M, McGrath G, et al. Engineering Leadership Program: Tracking Leadership Development of Students using Personalized Portfolios//38th ASEE/IEEE Frontiers in Education Conference, 2008.

[5] Zhang D L. Sino-French cooperation in cultivating leading talents in the field of engineering $[\mathrm{J}]$. International talent communication, 2010(5): 6262. 
[6] Li Z Q. Exploration and Analysis of Undergraduates' Engineering Leadership Training[J]. Continuing education research, 2013(8): 122124.

[7] http://www.huaue.com/unews 2014/2016111283127.htm

[8] Lei H, Crawley E. Develop Engineering Leadership to Lead the Development of the World - MIT Gordon Engineering Leadership Program Overview[J]. Tsinghua University Education Research, 2010, 31(1): 77-83.

[9] Cui J, Wang X. Develop Engineering Leader: Engineering Leadership Education at MIT[J]. Higher science education, 2010(6): 30-35.
[10] Ruth Graham, Edward Crawley, Bruce R. Mendelsohn, Engineering leadership education: A snapshot review of international good practice, White Paper sponsored by the Bernard M. Gordon - MIT Engineering Leadership Program, 2009

[11] Lin J, Xu Z D. International Eng ineering Leadership Education and Its En lightenment to China (I) [J]. Higher Engineering Education Research, 2014(3): 7-17. 